Bulletin of the Natural History Museum, 2015, 8: 169-191.

Received 18 Feb 2015; Accepted 03 Dec 2015.

doi:10.5937/bnhmb1508169D

UDC: $58-051(497.11)$

Review paper

\title{
BOTANISTS WHO HAVE MADE A CONTRIBUTION TO RESEARCH INTO THE FORESTS OF SERBIA
}

\author{
ANKA DINIĆ \\ University of Belgrade, Institute for Biological Research "Siniša Stankovič"
}

Looking for data and information that were used to prepare the text of the forest cover of Serbia (Dinić, A.: Šumovitost Srbije nekad $i$ sad) has required going through a number of papers and books on the Serbian forest vegetation, published from the $19^{\text {th }}$ century to modern times. This is when the idea was born to briefly present the biographies of researchers into the forest vegetation of Serbia and their work in the field. The paper: Dinić, A: The most important researches of forests in Serbia, published in 2012, presents the biographies of scientists who have made the greatest and most significant contribution to what we know about the forest vegetation in Serbia today.

This paper presents the biographies of several other botanists who have encompassed their active careers in the $20^{\text {th }}$ century, and who have dealt with the forests of Serbia from various aspects, as well as the botanists who were not exclusively or primarily engaged in the forests but whose papers include data relevant for understanding the composition, structure and the dynamics of changes undergone by the forests in Serbia or individual forest species. 
TeOdoR SošKa (Austro-Hungarian Empire, today Czech Republic: Opava 1876-1948 Belgrade) was educated in Opava, Vienna and Dalhem (Berlin) and arrived in Serbia in 1907. He had worked for 40 years in the Belgrade's Botanical Garden, leaving behind a rich herbarium. He had published 13 scientific papers among which the paper on forest vegetation is titled: Kratak pregled vegetacije južne Srbije (1937).

ŽIVKo SLAVNIĆ (Senta 1910-1975 Sarajevo) was educated in Senta and he had graduated in Paris while his Doctoral degree received in Vienna. He had worked in secondary schools in Serbia and Macedonia, and later in Novi Sad at the Higher Pedagogical School and as research associate at the Institute of Agricultural Research, as well as at the Faculty of Philosophy in Sarajevo (from 1960: the Faculty of Sciences) where for many years he was chief of Department of Botany and director of the Institute of Biology. He was a regular member of Matica Srpska in Novi Sad and editor in chief of scientific journal Godišnjak Biološkog instituta u Sarajevu, as well as the first president of the Society of Biosystemists of Yugoslavia. He was awarded the Labor Medal with a Golden Wreath. He has published over 60 scientific papers, of which the significant to the field of forest vegetation are: Nizinske šume Vojvodine (1952) and Florogeneza nizinskih šuma Vojvodine (1954).

VILOTIJE BLEČIĆ (Montenegro: Seljani near Plužina 1911-1981 Belgrade) was educated in Gacko and Pljevlja; he had graduated at the Faculty of Philosophy in Belgrade and received his Doctoral degree at the Faculty of Sciences in Belgrade (Forest vegetation and vegetation of rocks and screes of the Piva river valley). Prior to the World War II he worked as assistant for Botany at the Faculty of Philosophy in Belgrade (from 1947: Faculty of Sciences). After the War, he worked for a short time as a head of Education in the Government of Montenegro, after which he returned to the Faculty of Philosophy in Belgrade, where he advanced to the position of tenured professor. He was head of the Department of Botany, and head of the Botanical Institute and the Botanical Garden. He was awarded the ' $13^{\text {th }}$ July Award' of the Socialist Republic of Montenegro, the 'October Award' of the City of Belgrade, the Labour Medal with a Golden Wreath and the Certificate of Appreciation of the University in Kragujevac. He was a regular member of the Science and Art Society of Montenegro, later on the Montenegrin Academy of Sciences and Arts. His papers relevant to the field of forest vegetation are: Prilog poznavanju smrčevih šuma Golije planine (1962) and Šuma cera i borovnice (Myrtillo-Quercetum cerris ass. nova) (1974).

DUŠAN ČolIĆ (Smederevo 1913-1995 Belgrade) was educated in Smederevo and Ćuprija; he had graduated at the Faculty of Agriculture and 
Forestry in Zemun (Belgrade) and received his Doctoral degree at the Faculty of Forestry in Belgrade (Fire as an ecological factor in the succession of Serbian spruce communities and the reduction of its areal). $\mathrm{He}$ worked at the Institute for the Protection of Nature and Scientific Research of Natural Rarities in Belgrade, and at the Institute for Biological Research in Belgrade, and was director of the Institute for the Protection of Nature. He was an associate at the Institute for Biological Research, Institute of Forestry, Faculty of Architecture and the Faculty of Sciences in Belgrade. He had written 40 scientific papers, of which approximately 20 contain results of the study of Serbian spruce (Picea omorika). His papers significant to the field of forest vegetation are: Staništa Pančićeve omorike na desnoj strani Drine (1953), Neki pionirski karakteri Pančićeve omorike i njena uloga u sukcesiji biljnih zajednica (1957), Asocijacija sa pančićevom omorikom (Picea omorika Panč.) na močvarnom staništu (1958), Prilog poznavanju ekologije vegetativnog razmnožavanja Pančićeve omorike (Picea omorika Panč.) (1959), Poreklo i sukcesija šumskih zajednica sa Pančićevom omorikom (Picea omorika Panč.) na planini Tari (1965), Požar kao ekološki faktor u sukcesiji zajednica pančićeve omorike $i$ redukovanju njenog areala (1967).

MiODRAG GlišIĆ (Negotin 1921-1982 Belgrade) had graduated at the Faculty of Agriculture and Forestry in Zemun (Belgrade) and received his Doctoral degree at the Faculty of Forestry in Belgrade (Chestnut (Castanea sativa Mill.) in Serbia and its biological and ecological variability). He worked at the Institute of Forest Research in Sarajevo and at the Institute for Forestry and Wood Industry in Belgrade. He had published more than 100 scientific papers, of which the following are significant to the field of forest vegetation: Pitomi kesten (Castanea sativa Mill.) u Srbiji $i$ njegov biološki i ekološki varijabilitet (1975), Šumske fitocenoze privrednih jedinica ,Miroč “ $i$,Crni vrh“ (1976), Regresione sukcesije i degradacione faze šume sladuna i cera (Quercetum farnetto-cerris Rudski) u Grdeličkoj klisuri (1977).

MelaniJa ObRadović (Temerin 1922-2009 Novi Sad) had been educated in Temerin, Futog and Kulpin. She had completed the Higher Pedagogical School in Novi Sad and graduated at the Faculty of Philosophy in Sarajevo, where she had also received her Doctoral degree (Phytogeographical analysis of the flora of Fruška Gora). She worked in factory "Kulpin" in Novi Sad, from which she transferred to the Provincial Council of Vojvodina, and then to the Central Council of Yugoslavia. She was an assistant at the Higher Pedagogical School in Novi Sad, from which she transferred to the Faculty of Philosophy (from 1969: Faculty of Sciences) in Novi Sad, where she advanced to the position of tenured professor. She was awarded the ' $7^{\text {th }}$ July Award' of the Socialist Republic of Serbia, the 
Certificate of Appreciation of the city of Novi Sad and the People's Medal of Merit with a Silver Wreath. She had written approximately 100 scientific papers, of which the significant to the field of forest vegetation is Biljnogeografska analiza flore Fruške gore (1966).

VLADIMIR VelJović (Kragujevac: Drača 1923-1997 Belgrade) was educated in Kragujevac; he had graduated at the Faculty of Agriculture in Zemun (Belgrade) and the Faculty of Sciences in Sarajevo, and received his Doctoral degree at the Faculty of Sciences in Belgrade (Vegetation in the vicinity of Kragujevac). He was a professor at the Faculty of Sciences in Kragujevac. He had published approximately 50 scientific papers, of which the following are significant to the field of forest vegetation: Vegetacija okoline Kragujevca (1967), Šume belograbića (Carpinus orientalis L.) u slivu Gruže (1980), Analiza promena florističkih sastava biljnih zajednica Šumadije i Pomoravlja od Košaninovog doba do danas (1991).

RADOJE BoGoJević (Despotovac: Trućevac 1923-1989 Belgrade) had completed the Higher Pedagogical School in Belgrade and graduated at the Faculty of Sciences in Belgrade, where he also received his Doctoral degree (Ecological study of fragments of steppe vegetation in Višnjička Kosa near Belgrade). He was a professor at the Faculty of Sciences in Belgrade and Kragujevac, as well as director of the Institute of Botany and the Botanical Garden of the University of Belgrade. He had published approximately 50 scientific papers, of which the following are significant to the field of forest vegetation: Prilog poznavanju šuma endemičnih borova munike (Pinus heldreichii) i molike (Pinus peuce) na severnoj strani Šarplanine $i$ njenim Metohijskim ograncima (1962), Vegetacijska zonalna pripadnost Višnjičke kose kraj Beograda i njene okoline (1965-1966), Floristička i fitocenološka ispitivanja vegetacije na Višnjičkoj kosi kraj Beograda (1965-1966), Euphorbio-Paliuretum spinae-christi R. Bog. nova termofilna zajednica drača (Paliurus spina-christi Mill.) i mlečike (Euphorbia pannonica Host) na Višnjičkoj kosi kraj Beograda (1969).

MILORAD POPOVIĆ (Niš 1923-2010 Belgrade) was educated in Niš and Požarevac; he had graduated at the Faculty of Forestry in Belgrade, where he also received his Doctoral degree (Dynamics of organic production of beech (Fagus moesiaca /Domin, Maly/Czeczott) in various plant communities on mount Kopaonik). He worked at the Institute for Biological Research "Siniša Stankovic'" in Belgrade. He was awarded the 'October Award' of the City of Belgrade. He had published more than 50 scientific papers, of which the following are significant to the field of forest vegetation: Semene godine bukve (Fagus moesiaca Domin, Maly) na Ostrozubu (1952), Bukove i smrčeve šume Kopaonika (1954), Individualni varijabilitet smrče (Picea excelsa L.) na Kopaoniku (1972), Grupni 
varijabilitet smrče (Picea excelsa L.) na Kopaoniku (1973), Biljne zajednice i staništa Stare planine (1978).

VoJISLAV NiKolić (Prizren: Suva Reka 1925-1988 Belgrade) was educated in Prizren, Prokuplje and Čačak; he had graduated at the Faculty of Sciences in Belgrade, where he also received his Doctoral degree (Study of spores and pollen from the Pliocene lignite of the Kosovo basin with reference to the current appearance of the vegetation of Kosovo). His dissertation was published in English by Foundation of Smithsonian Institution in Washington. He spent his entire career at the Natural History Museum in Belgrade, where he advanced to the position of senior curator and senior research associate. For a while he served as acting director of the Natural History Museum. He was awarded the 'October Award' of the City of Belgrade and the ' $7^{\text {th }}$ July Award' of the Socialist Republic of Serbia. He had published more than 70 scientific papers, of which the significant to the field of forest vegetation is Flora Jablanika i Medvednika sa osvrtom na vegetaciju (1958).

NIKOLA DiKLIĆ ${ }^{1}$ (Sombor: Kupusina 1925-2008 Belgrade) had graduated at the Faculty of Sciences in Belgrade and earned his Doctoral degree in Ljubljana (Monograph of the genus Vicia L. in Yugoslavia). He spent his entire career at the Natural History Museum, where he advanced to the position of museum advisor and scientific advisor. He was a member of the Committee for the Flora and Vegetation of the Serbian Academy of Sciences and Arts and editor of the tenth volume in the edition Flora of SR Serbia, two books in the edition of collected works of Josif Pančić (1 and 2) and scientific journal Glasnik Prirodnjačkog muzeja u Beogradu, as well as a prominent member and official in the international scientific botanical organisation OPTIMA. He was awarded the 'October Award' of the City of Belgrade, the ' $7^{\text {th }}$ July' award of the Republic of Serbia, the Award "Mihajlo Valtrovic" of the Community of Museums of SR Serbia (now: the Museum association of Serbia), as well as international awards: the Silver Plaque awarded by Fondazione internazionale pro Herbario Mediterraneo, and the OPTIMA Gold Medal. He had published 586 scientific papers, of which the following are significant to the field of forest vegetation: Životne forme biljnih vrsta i biološki spektar flore SR Srbije (in: Vegetacija Srbije 1, 1984), Vegetacija šibljaka (in: Vegetacija Srbije 2(1), 1997), Flora šibljaka na planini Miroču u istočnoj Srbiji, sa osvrtom na vegetaciju (1958), Prilog poznavanju šumskih $i$ livadskih fitocenoza

\footnotetext{
${ }^{1}$ A comprehensive review and analysis of the life, work, achievements, role and importance of Nikola Diklić is available in: Vasic, O.: Nikola Diklić (1925-2008). - Bulletin of the Natural History Museum in Belgrade 2: 155-212, Belgrade, 2009 and Vasic, O.: Nikola Diklić (1925-2008). - Flora Mediterranea 18: 615-640, Palermo, 2008.
} 
Ozrena, Device i Leskovika kod Sokobanje (1962), Prilog poznavanju vegetacije šibljaka jorgovana (Syringa vulgaris L.) u istočnoj Srbiji (Eryngio-Syringetum vulgaris Diklić ass. nova) (1965), Flora Jablanika $i$ Medvednika sa osvrtom na vegetaciju (1958).

MiLOVAN GaJĆ (Belgrade 1926-1994) was educated in Belgrade. He had graduated at the Faculty of Agriculture and Forestry in Zemun (Belgrade) and received his Doctoral degree at the Faculty of Forestry in Belgrade (Phytocenoses and habitats of the Rudnik mountain and the phases of their degradation), where he spent his entire career, advancing to the position of tenured professor. He was awarded the 'October Award' of the City of Belgrade, the ' $7^{\text {th }}$ July' award of the Republic of Serbia, the Medal for Bravery, and the Labor Medal with a Golden Wreath. He had published more than 200 scientific papers, of which the following are significant to the field of forest vegetation: $O$ vegetaciji Košutnjaka (1952), Prilog poznavanju hrastovo-grabovih šuma (Querceto-Carpinetum) Šumadije (1954), Fitocenoze i staništa planine Rudnik i njihove degradacione faze (1961), Flora Goča-Gvozdac (1984), Flora i vegetacija Golije i Javora (1989), Vegetacija nacionalnog parka Tara (1992), Omorika - Picea omorika (Pančić) Purkyne na području nacionalnog parka Tara (1994).

BuDislav TATIĆ (Prokuplje: Tulare 1926-2010 Belgrade) was educated in Leskovac and Prokuplje. He had graduated at the Faculty of Sciences in Belgrade, where he also earned his Doctoral degree (Flora and vegetation of Studena Planina mountain near Kraljevo). He worked as a teacher in the village of Rgaje (then Toplica district), later transferring to the Faculty of Sciences in Belgrade, where he advanced to the position of tenured professor. He was awarded the 'October Award' of the City of Belgrade and the ' $7^{\text {th }}$ July' award of the Republic of Serbia. He had published 100 scientific papers, of which the following are significant to the field of forest vegetation: Prilog poznavanju smrčevih šuma Golije planine (1962), Flora $i$ vegetacija Studene planine kod Kraljeva (1970), Šma cera i borovnice (Myrtillo-Quercetum cerris ass. nova) (1974), Nova reliktna zajednica crnog graba sa javorima (Aceri-Ostryetum carpinifoliae) na području jugozapadne Srbije (1986), Šume crnog $i$ belog bora, Acidofilne šume borova, Šume Pančićeve omorike (in: Vegetacija Srbije 2(2), 2006).

MLADEN KoRAĆ (Croatia: Lika: Debelo Brdo 1926-2011 Belgrade) was educated in Belgrade. He had graduated at the Faculty of Agriculture and Forestry in Zemun (Belgrade), and at the Faculty of Sciences in Belgrade. $\mathrm{He}$ received his Doctoral degree in Zagreb (Flora and vegetation of the Forest Area of the Juhor mountain). He worked as a teacher in a high school in Belgrade, and later transferred to the Faculty of Forestry in Belgrade where he became a tenured professor. He had published 50 
papers, of which the following are significant to the field of forest vegetation: O pojavi poligamije kod Populus tremula (1958), Sikare leske u dolini Lepenca (1958), Pančićeva omorika (Picea omorika Panč.) $i$ jonizujuće zračenje (1965), Smrča sa hrastolikom korom (1978), Šuma kitnjaka - Quercetum montanum Čer. et Jov. na planini Juhor (1985), Degradirani stadijum subasocijacije Carpinetosum orientalis asocijacije Quercetum montanum na Juhoru (1989).

JOSIP ERDEŠI (Bač 1927-2005 Sremska Mitrovica) was educated in Sombor; he had graduated at the Faculty of Agriculture and Forestry in Zemun (Belgrade) and received his Doctoral degree at the Faculty of Forestry in Belgrade (Phytocenoses of forests of South-West Srem). He worked at the Forestry Management in Morović (Forest Estate Sremska Mitrovica), was head of the Forestry Management in Višnjićevo, and independent officer at the Forest Estate Sremska Mitrovica. Within the Forest Estate, he had founded a Pedological Laboratory and organized a Seed Collection Service. He had published 50 scientific papers, of which the following are significant to the field of forest vegetation: Usukanost kod jasena (1957), Nizinska jasika Vojvodine i siva topola (1965), Fitocenoze šuma jugozapadnog Srema (1971), Nove forme i nalazišta lužnjaka u SRS (1977), Nove forme i nova nalazišta cera u SRS i SFRJ(1977), Ikonografija hrasta lužnjaka Jugoslavije (1985).

ALEKSANDAR TUCOVIĆ (Zemun 1928-2004 Belgrade) was educated in Belgrade. He had graduated at the Faculty of Forestry and the Faculty of Sciences in Belgrade. He had earned his Doctoral degree at the Faculty of Forestry (Systematic and bio-ecological studies of Black Poplar (Populus nigra L. in Serbia)), where he had spent his entire career, advancing to the position of tenured professor. He also taught at the Faculty of Agriculture in Novi Sad. He was a member of the New York Academy of Sciences. He was awarded the 'October Award' of the City of Belgrade, the ' $7^{\text {th }}$ July' award of the Republic of Serbia, the Golden Plaque of the Faculty of Forestry and the Forest Directorate of Deliblatski Pesak, as well as two Certificates of Appreciation by the US Ministry of Agriculture. He had written over 300 scientific papers, of which the following are significant to the field of forest vegetation: Prilog poznavanju dendroflore Beograda $i$ okoline (1954), Uticaj niskih temperatura na alohtonu dendrofloru Beograda i okoline u toku zime 1955/56 godine (1957), Novi hibridi topola proizvedeni u 1958. godini (1960), Masovna i individualna selekcija bukve u Srbiji (1967), Autohtone topole Deliblatske peščare (1969), Individualna selekcija stabala domaćeg (Juglans regia L.) i crnog oraha (Juglans nigra L.) (1973), Genetika hrastova lužnjaka i kitnjaka (Quercus robur L. $i$ Quercus petraea Liebl.) (1975). 
VIDAK JOVANOVIĆ (Leskovac 1931-2000) was educated in Leskovac; he had graduated at the Higher Pedagogical School in Niš and the Faculty of Sciences in Skopje, obtaining his Master's degree in Zagreb (Flora and vegetation of the northern part of Kukavica in South-East Serbia) and his Doctoral degree in Novi Sad (Meadow vegetation of South-East Serbia Radan and Goljak mountains, part of Kukavica, and their environment). He worked as elementary school teacher and Education advisor in Leskovac. He was a professor at the Higher Pedagogical School in Belgrade and the Faculty of Technology in Leskovac, and he also taught at the Faculty of Pedagogy in Vranje. He had published 50 scientific papers, of which the following are significant to the field of forest vegetation: Planina Kukavica u jugoistočnoj Srbiji i vegetacija njenog severnog dela (1977), Šumska vegetacija šire okoline Medveđe u južnoj Srbiji (1984), Rasprostranjenje fitocenoze hrasta sladuna (Quercetum farnetto Jov.) u Leskovačkoj kotlini (1982), Reliktna vegetacija u predelu Kozarnik-Klisura-Sv. Ilija u južnoj Srbiji (1982), Reliktna vegetacija Mrkonjskog visa u južnoj Srbiji (1983), Quercetum montanum s. lat. kao klimaregionalni tip šume južne Srbije (1984), Šuma pitomog kestena, kitnjaka i grabića (Carpino orientalisQuerco-Castanetum sativae ass. nova) u okolini Vranja (1998/1999).

ZAGORKA Uvalić TOMIĆ (Srpski Miletić: Odžaci 1938-) was educated in Sombor; she graduated at the Faculty of Forestry in Belgrade, where she received both her Master's (Phytocenoses of Lipovica) and Doctoral degrees (Phytocenoses of Hornbeam (Ostria carpinifolia Scop.) in Serbia). She spent her entire career at the Faculty of Forestry in Belgrade, where she advanced to the position of tenured professor. She is a member of the Committee for the Flora and Vegetation of the Serbian Academy of Sciences and Arts. She has published 80 scientific papers, of which the following are the most important: Fitocenoze Lipovice (1972), Fitocenoze bukve na Bukulji (1976), Ekološke jedinice Banjske šume u okolini Bora, Fitocenoze crnog graba (Ostrya carpinifolia Scop.) u Srbiji (1980), Šumski ekosistemi u širem području Obedske bare (1984), Zajednica OrnoQuercetum-cerris virgilianae Jov. et. Vuk. 1977 na južnom obodu Panonije (1991), Zajednica crnoga bora i crnoga graba - Ostryo-Pinetum nigrae Čol. 1965. na Tari (1994), Zajednica Orno-Ostryetum Aich. 33 u refugijumima jugozapadne Srbije (2000), Zajednica Quercetum farnettocerris scardicum Krasn. 1968 (2000), Prilog poznavanju asocijacije Quercetum montanum Čer. et. Jov. 1953. u severoistočnoj Srbiji (2003), Šume crnog graba, Šume crnog i belog bora, Acidofilne šume borova, Pregled sintaksona šumske vegetacije Srbije (in: Vegetacija Srbije 2(2), 2006), Izbor vrsta za pošumljavanje $i$ melioracije u centralnoj Srbiji (2011). 
ANKA DINIĆ (Belgrade 1938-) was educated in Belgrade, where she graduated at the Faculty of Forestry. She received her Master's and Doctoral degrees at the Faculty of Sciences in Belgrade (Hornbeam (Carpinus betulus L.) in the forest communities of Fruška Gora; Ecology and variability of Hornbeam (Carpinus betulus L.) and its participation in the forest communities of Northern Serbia). She remained at the Institute for Biological Research "Siniša Stanković" in Belgrade throughout her career, advancing to the position of scientific advisor. She is a member of Matica Srpska and the Committee for the Flora and Vegetation of the Serbian Academy of Sciences and Arts. She was awarded the 'October Award' of the City of Belgrade, the Diploma of the Serbian Biological Society and the Certificate of Appreciation of the National Institute for the Protection of Nature of SR Serbia. She has published close to 250 scientific papers, of which the following are the most important: Grab (Carpinus betulus L.) u šumskim zajednicama Fruške gore (1970), Fitocenoza graba (Chrysosplenio-Carpinetum betuli ass. nova) na aluvijalno-deluvijalnom nanosu u severnoj Srbiji (1972), Ekološka studija graba (Carpinus betulus L.) na primeru tipičnog vegetacijskog transekta na Avali (1975), Varijabilitet $i$ ekološka diferencijacija graba (Carpinus betulus L.) u severnoj Srbiji (1975), Fitocenoza kitnjaka i graba kao klimaregionalni tip šume na malim masivima u severnoj Srbiji, na obodu Panonske nizije (1978), Biljne zajednice i staništa Stare planine (1978), Uticaj letnje suše na međusobne odnose biljnih vrsta i sastavi dinamiku klimatogene zajednice sladuna icera (Quercetum farnetto cerris serbicum Rudski) (1984), Eksperimentalna ispitivanja klijavosti semena Pančićeve omorike na različitim staništima u rezervatu Crveni potok na planini Tari (1989), Eksperimentalna fitocenologija šumskih ekosistema Srbije (1994), Sveza kitnjakovo-grabovih i čistih grabovih šuma (Carpinion betuli moesiacum B. Jov. 1986) (in Vegetacija Srbije 2(1),1997), Ekološka diferencijacija vrsta šumskog drveća u Srbiji (2004), Šume smrče, Šume Pančićeve omorike (in Vegetacija Srbije 2(2), 2006).

\section{REFERENCES}

Blečić, V., Tatić, B. (1962): Prilog poznavanju smrčevih šuma Golije planine. Glasnik Prirodnjačkog muzeja u Beogradu B18: 39-47.

Blečić, V., Tatić, B., Atanacković, B. (1974): Šuma cera i borovnice (MyrtilloQuercetum cerris ass. nova). In: Zbornik radova sa Simpozijuma povodom 100. godišnjice prve jugoslovenske dendrologije Josifa Pančića. - Akademija nauka i umjetnosti Bosne i Hercegovine, Beograd/Sarajevo, 197-204.

Bogojević, R. (1965-1966): Floristička i fitocenološka ispitivanja vegetacije na Višnjičkoj kosi kraj Beograda. - Glasnik Botaničkog zavoda i Bašte Univerziteta u Beogradu 3(1-4): 79-99 (1968). 
Bogojević, R. (1965-1966): Vegetacijska zonalna pripadnost Višnjičke kose kraj Beograda i njene okoline. - Glasnik Botaničkog zavoda i Bašte Univerziteta u Beogradu 3(1-4): 43-78 (1968).

Bogojević, R. (1969): Euphorbio-Paliuretum spinae-christi R. Bog. - nova termofilna zajednica drača (Paliurus spina-christi Mill.) i mlečike (Euphorbia pannonica Host) na Višnjičkoj kosi kraj Beograda. - Ekologija, Beograd 4(2): 217-224.

Černjavski, P., Rudski, I., Soška, T. (1937): Kratak pregled vegetacije južne Srbije. - Spomenica povodom dvadesetpeto-godišnjice oslobođenja južne Srbije 1912-1937, Skoplje, 135-139.

Čolić, B. D. (1953): Staništa Pančićeve omorike na desnoj strani Drine. - Zaštita prirode, Beograd 4-5: 425-659.

Čolić, D. (1959): Prilog poznavanju ekologije vegetativnog razmnožavanja Pančićeve omorike (Picea omorika Panč.). - Arhiv bioloških nauka, Beograd 11(14): 41-66 (1960).

Čolić, B. D. (1957): Neki pionirski karakteri Pančićeve omorike i njena uloga u sukcesiji biljnih zajednica. - Arhiv bioloških nauka, Beograd 9(1-4): 51-60 (1959).

Čolić, D. (1965): Poreklo i sukcesija šumskih zajednica sa Pančićevom omorikom (Picea omorika Panč.) na planini Tari. - Zaštita prirode, Beograd 29-30: 65-90.

Čolić, D. (1967): Požar kao ekološki faktor u sukcesiji zajednica pančićeve omorike i redukovanju njenog areala. - Zaštita prirode, Beograd 33/1966 [Posebno izdanje].

Čolić, D., Gigov, A. (1958): Asocijacija sa pančićevom omorikom (Picea omorika Panč.) na močvarnom staništu. - Biološki institut N. R. Srbije, Beograd, Posebna izdanja 5(2): 1-131.

Diklić, N. (1958): Flora šibljaka na planini Miroču u istočnoj Srbiji, sa osvrtom na vegetaciju. - Glasnik Prirodnjačkog muzeja u Beogradu B12: 46-64.

Diklić, N. (1962): Prilog poznavanju šumskih i livadskih fitocenoza Ozrena, Device i Leskovika kod Sokobanje. - Glasnik Prirodnjačkog muzeja u Beogradu B18: 49-83.

Diklić, N. (1965): Prilog poznavanju vegetacije šibljaka jorgovana (Syringa vulgaris L.) u istočnoj Srbiji (Eryngio-Syringetum vulgaris Diklić ass. nova). Glasnik Prirodnjačkog muzeja u Beogradu B20: 57-76.

Diklić, N. (1984): Životne forme biljnih vrsta i biološki spektar flore SR Srbije. In: Sarić, M.R., Kojić, M. (eds): Vegetacija SR Srbije 1: 291-316. - Srpska Akademija nauka i umetnosti, Beograd.

Diklić, N. (1997): Vegetacija šibljaka/Tha Shibliak Vegetation. In: Sarić, M.R., Vasić. O. (eds): Vegetacija Srbije 2(1): 339-404. - Srpska Akademija nauka i umetnosti, Beograd.

Dinić, A. (1970): Grab (Carpinus betulus L.) u šumskim zajednicama Fruške gore. - Matica srpska, Zbornik za prirodne nauke 39: 82-116.

Dinić, A. (1972): Fitocenoza graba (Chrysosplenio-Carpinetum betuli ass. nova) na aluvijalno-deluvijalnom nanosu u severnoj Srbiji. - Matica srpska, Zbornik za prirodne nauke 43: 138-148.

Dinić, A. (1975): Ekološka studija graba (Carpinus betulus L.) na primeru tipičnog vegetacijskog transekta na Avali. - Glasnik Instituta za botaniku i Botaničke bašte Univerziteta u Beogradu 10(1-4): 31-76. 
Dinić, A. (1975): Varijabilitet i ekološka diferencijacija graba (Carpinus betulus L.) u severnoj Srbiji. - Matica srpska, Zbornik za prirodne nauke 48: 22-114.

Dinić, A. (1978): Fitocenoza kitnjaka i graba kao klimaregionalni tip šume na malim masivima u severnoj Srbiji, na obodu Panonske nizije. - Matica srpska, Zbornik za prirodne nauke 55: 155-163.

Dinić, A. (1984): Uticaj letnje suše na međusobne odnose biljnih vrsta i sastav i dinamiku klimatogene zajednice sladuna i cera (Quercetum farnetto cerris serbicum Rudski). - Ekologija, Beograd 19(1): 1-15.

Dinić, A. (1989): Eksperimentalna ispitivanja klijavosti semena Pančićeve omorike na različitim staništima u rezervatu Crveni potok na planini Tari. - Zaštita prirode, Beograd 41-42: 87-95.

Dinić, A. (1994): Eksperimentalna fitocenologija šumskih ekosistema Srbije. Matica srpska, Novi Sad.

Dinić, A. (1997): Sveza kitnjakovo-grabovih i čistih grabovih šuma (Carpinion betuli moesiacum Rudski B. Jov. 1986)/Alliance sessile oak-hornbeam forests and pure hornbeam forests. In: Sarić, M.R., Vasić, O. (eds): Vegetacija Srbije 2(1): 281-309. - Srpska akademija nauka i umetnosti, Beograd.

Dinić, A. (2012): Šumovitost Srbije nekad i sad. In: Stefanović, D., Vasić, O. (eds): Drvo ili život sam, 73-83. - Prirodnjački muzej, Srpska akademija nauka i umetnosti, Beograd.

Dinić, A: (2012): The most important researches of forests in Serbia/Najznačajniji istraživači šuma u Srbiji. - Bulletin of the Natural History Museum in Belgrade 5: 103-114, 115-122.

Dinić, A., Tatić, B. (2006): Šume Pančićeve omorike/The Serbian spruce forests. In: Škorić, M.D., Vasić, O. (eds): Vegetacija Srbije 2(2): 213-244. - Srpska akademija nauka i umetnosti, Beograd.

Dinić, A., Jovanović, V., Mišić, V., Kalinić, M. (1998/1999): Šuma pitomog kestena, kitnjaka i grabića (Carpino orientalis-Querco-Castanetum sativae ass. nova) u okolini Vranja. - Vranjski glasnik, Vranje 31-32: 185-198.

Erdeši, J. (1957): Usukanost kod jasena. - Šumarstvo, Beograd 10(5-6): 345-350.

Erdeši, J. (1965): Nizinska jasika Vojvodine i siva topola. - Topola, Beograd 5254: $8-27$.

Erdeši, J. (1971): Fitocenoze šuma jugozapadnog Srema. - Gumsko gazdinstvo Sremska Mitrovica, Sremska Mitrovica.

Erdeši, J. (1985): Ikonografija hrasta lužnjaka Jugoslavije. - Glasnik Šumarskog fakulteta, Beograd, 64: 109-140.

Erdeši, J., Gajić, M. (1977): Nove forme i nova nalazišta cera u SRS i SFRJ. Glasnik Sumarskog fakulteta, Beograd 52: 91-97.

Erdeši, J., Čanak, M., Gajić, M. (1977): Nove forme i nalazišta lužnjaka u SRS. Glasnik Šmarskog fakulteta, Beograd 52: 83-89.

Gajić, M. (1952): O vegetaciji Košutnjaka. - Glasnik Šumarskog fakulteta, Beograd 5: $283-308$.

Gajić, M. (1954): Prilog poznavanju hrastovo-grabovih šuma (Querceto-Carpinetum) Šumadije. - Arhiv bioloških nauka, Beograd 6(1-2): 1-9.

Gajić, M. (1961): Fitocenoze i staništa planine Rudnik i njihove degradacione faze. - Glasnik Šumarskog fakulteta, Beograd 23: 1-114. 
Gajić, M. (1984): Flora Goča-Gvozdac. - Šumarski fakultet, Beograd.

Gajić, M. (1989): Flora i vegetacija Golije i Javora. - Šumarski fakultet, Beograd, OOUR Šumarstvo „Golija“, Ivanjica.

Gajić, M. (1992): Vegetacija nacionalnog parka Tara. - Šumarski fakultet, Beograd, Nacionalni Park Tara, Bajina Bašta.

Gajić, M., Vilotić, D., Karadžić, D., Mihajlović, Lj., Isajev, V. (1994): Omorika Picea omorika (Pančić) Purkyne na području nacionalnog parka Tara. Nacionalni park Tara, Bajina Bašta, Šumarski fakultet, Beograd.

Glišić, M. (1975): Pitomi kesten (Castanea sativa Mill.) u Srbiji i njegov biološki i ekološki varijabilitet. - Zbornik radova Instituta za šumarstvo i drvnu industriju, Beograd, Posebno izdanje 36: 51-195.

Glišić, M. (1976): Šumske fitocenoze privrednih jedinica „Miroč“ i „Crni vrh“. Zbornik radova Instituta za šumarstvo i drvnu industriju, Beograd 13-14: 75-107.

Glišić, M. (1977): Regresione sukcesije i degradacione faze šume sladuna i cera (Quercetum farnetto-cerris Rudski) u Grdeličkoj klisuri. - Šumarstvo, Beograd 5: 7-16.

Janković, M.M., Bogojević, R. (1962): Prilog poznavanju šuma endemičnih borova munike (Pinus heldreichii) i molike (Pinus peuce) na severnoj strani Šarplanine i njenim metohijskim ograncima. - Arhiv bioloških nauka, Beograd 14(3-4): 143-155 + I-IV.

Jovanović, V. (1977): Planina Kukavica u jugoistočnoj Srbiji i vegetacija njenog severnog dela. - Leskovački zbornik, Leskovac 17: 271-299.

Jovanović, B., Tucović, A. (1960): Novi hibridi topola proizvedeni u 1958. godini. - Glasnik Prirodnjačkog muzeja u Beogradu B16: 3-22.

Jovanović, M., Tucović, A. (1975): Genetika hrastova lužnjaka i kitnjaka (Quercus robur L. i Quercus petraea Liebl.). - Annales forestales, Zagreb 7-2/2: 23-53.

Jovanović, B., Jović, N., Tomić, Z. (1984): Šumski ekosistemi u širem području Obedske bare. - Glasnik Šumarskog fakulteta, Beograd A62: 65-70.

Jovanović, V., Mišić, V., Dinić, A. (1984): Šumska vegetacija šire okoline Medveđe u južnoj Srbiji. - Leskovački zbornik, Leskovac 24: 365-373.

Jović, N., Tomić, Z. (1980): Ekološke jedinice Banjske šume u okolini Bora. Fitocenoze crnog graba (Ostrya carpinifolia Scop.) u Srbiji. - Glasnik Šumarskog fakulteta, Beograd A54: 73-77.

Lazarević, Z., Korać, M. (1958): O pojavi poligamije kod Populus tremula. Šumarstvo, Baorrad 11(1-2): 66-68.

Korać, M. (1958): Šikare leske u dolini Lepenca. - Šumarstvo, Beograd 11(3-4): 191-199.

Korać, M. (1965): Pančićeva omorika (Picea omorika Panč.) i jonizujuće zračenje. - Šumartvo, Beograd 18(3-5): 135-145.

Korać, M. (1978): Smrča sa hrastolikom korom. - Šumarstvo, Beograd 31(1): 47-51.

Korać, M. (1985): Šuma kitnjaka - Quercetum montanum Čer. et Jov. na planini Juhor. - Šumartvo, Beograd 38(2-3): 13-28.

Korać, M. (1989): Degradirani stadijum subasocijacije Carpinetosum orientalis asocijacije Quercetum montanum na Juhoru. - Sumarstvo, Beograd 43(1): 3-10.

Mišić, V., Dinić, A. (2004): Ekološka diferencijacija vrsta šumskog drveća u Srbiji. - Matica srpska, Novi Sad. 
Mišić, V., Dinić, A. (2006): Šume smrče/The Norway spruce forests. In: Škorić, M.D., Vasić, O. (eds): Vegetacija Srbije 2(2): 171-193. - Srpska akademija nauka i umetnosti, Beograd.

Mišić, V., Popović, M. (1954): Bukove i smrčeve šume Kopaonika. - Arhiv bioloških nauka, Beograd 6(1-2): 1-24.

Mišić, V., Dinić, A., Jovanović, V. (1982): Rasprostranjenje fitocenoze hrasta sladuna (Quercetum farnetto Jov.) u Leskovačkoj kotlini. - Arhiv bioloških nauka, Beograd 34(1-4): 3P-4P.

Mišić, V., Dinić, A., Jovanović, V. (1982): Reliktna vegetacija u predelu KozarnikKlisura-Sv. Ilija u južnoj Srbiji. - Arhiv bioloških nauka, Beograd 34(1-4): 1P-2P.

Mišić, V., Dinić, A., Jovanović, V. (1983): Reliktna vegetacija Mrkonjskog visa u južnoj Srbiji. - Prilozi ANU Makedonije 4(1-2): 143-152.

Mišić, V., Dinić, A., Jovanović, V. (1984): Quercetum montanum s. lat. kao klimaregionalni tip šume južne Srbije. - Arhiv bioloških nauka, Beograd 36(14): 7P-8P.

Mišić, V., Popović, M., Čolić, D. (1972): Individualni varijabilitet smrče (Picea excelsa L.) na Kopaoniku. - Glasnik Prirodnjačkog muzeja u Beogradu B27: 51-61.

Mišić, V., Popović, M., Čolić, D. (1973): Grupni varijabilitet smrče (Picea excelsa L.) na Kopaoniku. - Glasnik Prirodnjačkog muzeja u Beogradu B28: 41-60.

Mišić, V., Jovanović-Dunjić, R., Popović, M., Borisavljević, Lj., Antić, M., Dinić, A., Danon, J., Blaženčić, Ž. (1978): Biljne zajednice i staništa Stare planine. Posebna izdanja 511, Odeljenje prirodno-matematičkih nauka 49: 1-389, Srpska akademija nauka i umetnosti, Beograd.

Nikolić, V., Diklić, N. (1958): Flora Jablanika i Medvednika sa osvrtom na vegetaciju. - Glasnik Prirodnjačkog muzeja u Beogradu B12: 65-98.

Obradović, M. (1966): Biljnogeografska analiza flore Fruške gore. - Matica srpska, Novi Sad.

Petković, B., Tatić, B., Marin, P. (1986): Nova reliktna zajednica crnog graba sa javorima (Aceri-Ostryetum carpinifoliae) na području jugozapadne Srbije. Glasnik Instituta za botaniku i Botaničke bašte Univerziteta u Beogradu 20: 55-64.

Popović, M. (1952): Semene godine bukve (Fagus moesiaca Domin, Maly) na Ostrozubu. - Zbornik radova SAN, Inst. za ekologiju i biogeografiju 3: 103-112.

Slavnić, Ž. (1952): Nizinske šume Vojvodine. - Zbornik za prirodne nauke Matice srpske 2: 17-38.

Slavnić, Ž. (1954): Florogeneza nizinskih šuma Vojvodine. - Zbornik za prirodne nauke Matice Srpske 5: 61-86.

Tatić, B. (1970): Flora i vegetacija Studene planine kod Kraljeva. - Glasnik Botaničkog zavoda i Bašte Univerziteta u Beogradu 4(1-4): 27-72.

Tatić, B., Tomić, Z. (2006): Acidofilne šume borova/The acidophilous pine forests. In: Škorić, M.D., Vasić, O. (eds): Vegetacija Srbije 2(2): 195-200. - Srpska akademija nauka i umetnosti, Beograd.

Tatić, B., Tomić, Z. (2006): Šume crnog i belog bora/The Austrian and Scotch pine foresrs. In: Škorić, M.D., Vasić, O. (eds): Vegetacija Srbije 2(2): 127-154. Srpska akademija nauka i umetnosti, Beograd.

Tomić, Z. (1976): Fitocenoze bukve na Bukulji. - Glasnik Sumarskog fakulteta A50: $149-154$. 
Tomić, Z. (1991): Zajednica Orno-Quercetum-cerris virgilianae Jov. et. Vuk. 1977 na južnom obodu Panonije. - Glasnik Šumarskog fakulteta, Beograd 73: 23-32.

Tomić, Z. (1994): Zajednica crnoga bora i crnoga graba - Ostryo Pinetum nigrae Čol. 1965. na Tari. - Glasnik Sumarskog fakulteta, Beograd 75-76: 75-83.

Tomić, Z. (2000): Zajednica Orno-Ostryetum Aich. 33 u refugijumima jugozapadne Srbije. - Glasnik Šumarskog fakulteta, Beograd 82: 177-191.

Tomić, Z. (2000): Zajednica Quercetum farnetto-cerris scardicum Krasn. 1968. u Lipovici kod Prištine. - Glasnik Šumarskog fakulteta, Beograd 83: 131-144.

Tomić, Z. (2003): Prilog poznavanju asocijacije Quercetum montanum Čer. et. Jov. 1953. u severoistočnoj Srbiji. - Glasnik Šumarskog fakulteta 87: 197-210.

Tomić, Z. (2006): Šume crnog graba/The hop-hornbeam forests. In Škorić, M.D., Vasić, O. (eds): Vegetacija Srbije 2(2): 31-68. - Srpska akademija nauka i umetnosti, Beograd.

Tomić, Z. (2006): Pregled sintaksona šumske vegetacije Srbije/The overview of syntaxa of forest vegetation in Serbia. In Škorić, M.D., Vasić, O. (eds): Vegetacija Srbije 2(2): 287-304. - Srpska akademija nauka i umetnosti, Beograd.

Tomić, Z., Rakonjac, Lj., Isajev, V. (2011): Izbor vrsta za pošumljavanje i melioracije u centralnoj Srbiji. - Institut za šumarstvo, Beograd.

Tucović, A. (1954): Prilog poznavanju dendroflore Beograda i okoline. - Glasnik Sumarskog fakulteta, Beograd 7: 243-252.

Tucović, A. (1957): Uticaj niskih temperatura na alohtonu dendrofloru Beograda i okoline u toku zime 1955/56 godine. - Zaštita bilja, Beograd 39-40: 43-55.

Tucović, A. (1967): Masovna i individualna selekcija bukve u Srbiji. - Zbornik Instituta za šumarstvo i drvnu industriju, Beograd 6: 73-104.

Tucović, A. (1969): Autohtone topole Deliblatske peščare. - Deliblatski pesak, Zbornik radova 1, Beograd, Jugoslovenski poljoprivredno-šumarski centar; Šumsko industrijski kombinat, Pančevo: 95-107.

Tucović, A., Marković, Lj., Valčić, V. (1973): Individualna selekcija stabala domaćeg (Juglans regia L.) i crnog oraha (Juglans nigra L.). - Zbornik radova Instituta za šumarstvo i drvnu industriju, Beograd 12: 27-39.

Uvalić-Tomić, Z. (1972): Fitocenoze Lipovice. - Šumarski fakultet, Beograd. 1-83.

Vasić, O. (2008): Nikola Diklić (1925-2008). - Flora Mediterranea 18: 615-640.

Vasić, O. (2009): Nikola Diklić (1925-2008). - Bulletin of the Natural History Museum in Belgrade 2: 155-212, Beograd.

Veljović, V. (1967): Vegetacija okoline Kragujevca. - Glasnik Prirodnjačkog muzeja u Beogradu B22: 5-108.

Veljović, V., Marković, A. (1980): Šume belograbića (Carpinus orientalis L.) u slivu Gruže. - Zbornik radova PMF u Kragujevcu 1: 47-63.

Veljović, V., Marković, A., Ognjanović, R. (1991): Analiza promena florističkih sastava biljnih zajednica Šumadije i Pomoravlja od Košaninovog doba do danas. - Simpozijum Nedeljko Košanin i botaničke nauke, Zbornik radova, Ivanjica/Beograd. 


\title{
БОТАНИЧАРИ КОЈИ СУ ДАЛИ ДОПРИНОС У ИСТРАЖИВАњУ ШУМА СРБИЈЕ
}

\author{
АнКА Динић \\ Институт за биолошка истраживања „Синиша Станковић“ Београд
}

У потрази за подацима и информацијама који су послужили за припрему текста о шумовитости Србије (Динић, А.: Шумовитост Србије некад и сад) било је неопходно да се из области истраживања шумске вегетације Србије прегледа велики број радова и књига, објављиваних од XIX века па до савременог доба. Тада је настала идеја да се укратко прикажу биографије истраживача шумске вегетације Србије и њихови радови из те области. У раду: Dinić, A: The most important researches of forests in Serbia, објављеном 2012, приказане су биографије научника који су остварили највећи и најзначајнији допринос у познавању шумске вегетације Србије.

У овом раду се приказују биографије још неколико ботаничара, који су свој активни радни век заокружили у XX веку, а који су се из различитих аспеката бавили шумама Србије, и ботаничара који се нису искључиво или првенствено бавили шумама али се у неким од њихових радова налазе подаци значајни за познавање састава, структуре и динамике промена шума у Србији, или о појединим шумским врстама.

ТЕодоР СошкА (Аустроугарска, данас Чешка република: Опава 1876-1948 Београд) се школовао у Опави, Бечу и Далему (Берлин), а у Србију је дошао 1907. У београдској Ботаничкој башти је радио 40 година, и за собом је оставио богати хербаријум. Објавио је 13 научних радова, а из области шумске вегетације је рад под насловом: Кратак преглед вегетације јужне Србије (1937).

Живко СлАвнић (Сента 1910-1975 Сарајево) се школовао у Сенти, дипломирао у Паризу и докторирао у Бечу. Радио је у средњим школама у Србији и Македонији, затим у Новом Саду на Вишој педагошкој школи и као научни сарадник Завода за пољопривредна истраживања, а затим на Филозофском факултету у Сарајеву (од 1960. 
Природно-математички факултет) где је дуги низ година био шеф Катедре за ботанику и директор Биолошког института. Био је редовни члан Матице српске у Новом Саду и главни уредник Годишњака Биолошког института у Сарајеву, као и први председник Друштва биосистематичара Југославије. Добитник је Ордена рада са златним венцем. Објавио је преко 60 научних радова, од којих су за шумску вегетацију значајни: Низинске шуме Војводине (1952) и Флорогенеза низинских шума Војводине (1954).

Вилотије БЛЕчиЋ (Црна Гора: Сељани код Плужина 1911-1981 Београд) се школовао у Гацком и Пљевљу, дипломирао на Филозофском факултету у Београду и докторирао на Природно-математичком факултету у Београду (Шумска вегетација и вегетација стена и точила долине реке Пиве). Пре II светског рата радио је као асистент за ботанику на Филозофском факултету у Београду (од 1947. Природно-математички факултет). После рата је кратко време био начелник за просвету у влади Црне Горе, а затим се вратио на Филозофски факултет у Београду где је напредовао до звања редовног професора. Био је шеф Катедре за ботанику, а затим и управник Ботаничког завода и Ботаничке баште. Добитник је Тринаестојулске награде СР Црне Горе, Октобарске награде града Београда, Ордена рада са златним венцем и Захвалнице Универзитета у Крагујевцу. Био је редовни члан Друштва Црне Горе за науку и уметност, односно Црногорске академије наука и умјетности. Радови значајни за шумску вегетацију су: Прилог познавању смрчевих шума Голије планине (1962) и Шума цера и боровнице (Myrtillo-Quercetum cerrisass. nova)(1974).

ДушАН Чолић (Смедерево 1913-1995 Београд) се школовао у Смедереву и Ћуприји, дипломирао на Пољопривредно-шумарском факултету у Земуну (Београд) и докторирао на Шумарском факултету у Београду (Пожар као еколошки фактор у сукцесији заједница Панчићеве оморике и редуковању њеног ареала). Радио је у Заводу за заштиту природе и научно проучавање природних реткости у Београду и у Институту за биолошка истраживања у Београду, а затим је био директор Републичког завода за заштиту природе. Био је и сарадник Института за биолошка истраживања, Института за шумарство, Архитектонског и Природно-математичког факултету у Београду. Написао је 40 научних радова од којих се у око 20 налазе резултати проучавања оморике (Picea omorika), а радови значајни за шумску вегетацију су: Станишта Панчићеве оморике на десној страни Дрине (1953), Неки пионирски карактери Панчићеве оморике и њена улога у сукцесији биљних заједница (1957), Асоцијација са панчићевом омориком (Picea omorika Panč.) на мочварном станишту (1958), Прилог познавању 
екологије вегетативног размножавања Панчићеве оморике (Picea отоrika Panč.) (1959), Порекло и сукцесија шумских заједница са Панчићевом омориком (Picea omorika Panč.) на планини Тари (1965), Пожар као еколошки фактор у сукцесији заједница панчићеве оморике и редуковању њеног ареала (1967).

МиодРАГ Глишић (Неготин 1921-1982 Београд) је дипломирао на Пољопривредно-шумарском факултету у Земуну (Београд) и докторирао на Шумарском факултету у Београду (Питоми кестен (Castanea sativa Mill.) у Србији и његов биолошки и еколошки варијабилитет). Радио је у Институту за шумарска истраживања у Сарајеву, а затим у Институту за шумарство и дрвну индустрију у Београду. Објавио је преко 100 научних радова, а значајни за шумску вегетацију су: Питоми кестен (Castanea sativa Mill.) у Србији и његов биолошки и еколошки варијабилитет (1975), Шумске фитоценозе привредних јединица „Мироч“ и „Црни врх“ (1976), Регресионе сукцесије и деградационе фазе шуме сладуна и цера (Quercetum farnetto-cerris Rudski) у Грделичкој клисури (1977).

МеЛАНИјА ОБРАдОвй (Темерин 1922-2009 Нови Сад) се школовала у Темерину, Футогу и Кулпину, а матурирала у Новом Саду. Завршила је Вишу педагошку школу у Новом Саду и дипломирала на Филозофском факултету у Сарајеву где је и докторирала (Биљногеографска анализа флоре Фрушке горе). Радила је у фабрици „Кулпин“у у Новом Саду, одакле је прешла у Покрајинско веће Војводине и затим у Централно веће Југославије. Била је асистент на Вишој педагошкој школи у Новом Саду, одакле је прешла на Филозофски факултет (од 1969. Природно-математички факултет) у Новом Саду где је напредовала до звања редовног професора. Добиник је Седмојулске награде СР Србије, повеље Новог Сада и Ордена заслуга за народ са сребрним венцем. Написала је око 100 научних радова од којих је за шумску вегетацију значајан рад Биљногеографска анализа флоре Фрушке горе (1966).

ВЛАДиМИР ВЕљовић (Крагујевац: Драча 1923-1997 Београд) се школовао у Крагујевцу, дипломирао на Пољопривредном факултету у Земуну (Београд) и Природно-математичком факултету у Сарајеву, и докторирао на Природно-математичком факултету у Београду (Вегетација околине Крагујевца). Био је професор на Природноматематичком факултету у Крагујевцу. Објавио је око 50 научних радова, а значајни за шумску вегетацију су: Вегетација околине Крагујевца (1967), Шуме белограбића (Carpinus orientalis L.) у сливу Груже (1980), Анализа промена флористичких састава биљних заједница Шумадије и Поморавља од Кошаниновог доба до данас (1991). 
РАДОJЕ БоГОЈЕвић (Деспотовац: Трућевац 1923-1989 Београд) је завршио Вишу педагошку школу у Београду и дипломирао на Природно-математичком факултету у Београду где је и докторирао (Еколошка студија фрагмената степске вегетације на Вишњичкој коси крај Београда). Био је професор на Природно-математичком факултету у Београду и у Крагујевцу, као и управник Института за ботанику и Ботаничке баште Универзитета у Београду. Објавио је око 50 научних радова, а за шумску вегетацију значајни су: Прилог познавању шума ендемичних борова мунике (Pinus heldreichii) и молике (Pinus peuce) на северној страни Шар-планине и њеним Метохијским огранцима (1962), Вегетацијска зонална припадност Вишњичке косе крај Београда и њене околине (1965-1966), Флористичка и фитоценолошка испитивања вегетације на Вишњичкој коси крај Београда (1965-1966), Euphorbio-Paliuretum spinae-christi R. Bog. - нова термофилна заједница драча (Paliurus spina-christi Милл.) и млечике (Euphorbia pannonica Host) на Вишњичкој коси крај Београда (1969).

МилоРАд ПоПовиЋ (Ниш 1923-2010 Београд) се школовао у Нишу и Пожаревцу, дипломирао на Шумарском факултету у Београду где је и докторирао (Динамика органске продукције букве (Fagus moesiaca /Domin, Maly/ Czeczott) у различитим фитоценозама на Копаонику). Радио је у Институту за биолошка истраживања „Синиша Станковић“ у Београду. Добитник је Октобарске награде града Београда. Објавио је преко 50 научних радова, а за шумску вегетацију су значајни: Семене године букве (Fagus moesiaca Domin, Maly) на Острозубу (1952), Букове и смрчеве шуме Копаоника (1954), Индивидуални варијабилитет смрче (Picea excelsa L.) на Копаонику (1972), Групни варијабилитет смрче (Picea excelsa L.) на Копаонику (1973), Биљне заједнице и станишта Старе планине (1978).

ВолислАв Николић (Призрен: Сува река 1925-1988 Београд) се школовао у Призрену, Прокупљу и Чачку и дипломирао на Природноматематичком факултету у Београду где је и докторирао (Проучавање спора и полена из плиоценског лигнита Косовског басена са освртом на данашњи изглед вегетације Косова). Дисертацију је на енглеском језику штампала фондација Smithsonian Institution из Вашингтона. Цео радни век је провео у Природњачком музеју у Београду где је напредовао до звања вишег кустоса и вишег научног сарадника, а кратко време је био и вршилац дужности директора Природњачког музеја. Добитник је Октобарске награде града Београда и Седмојулске награде СР Србије. Објавио је преко 70 научних радова а од значаја за шумску вегетацију је рад Флора Јабланика и Медведника са освртом на вегетацију (1958). 
НиколА Диклић ${ }^{1}$ (Сомбор: Купусина 1925-2008 Београд) је дипломирао на Природно-математичком факултету у Београду и докторирао у Љубљани (Монографија генуса Vicia L. у Југославији). Цео радни век је провео у Природњачком музеју где је напредовао до звања музејског саветника и научног саветника. Био је члан Одбора за флору и вегетацију Српске академије наука и уметности и уредник десетог тома из едиције Флора СР Србије, 2 књиге из едиције Јосиф Панчић сабрана дела (1 и 2) и часописа Гласник Природњачког музеја у Београду, као и угледни члан и функционер у међународној научној ботаничкој организацији OPTIMA. Добитник је Октобарске награде града Београда, Седмојулске награде СР Србије, Награде „Михајло Валтровић“ Заједнице музеја СР Србије (сада Музејско друштво Србије) и међународних награда: Сребрне плакете коју додељује Fondazione internazionale pro Herbario Mediterraneo и OPTIMA златне медаље. Објавио је 586 научних радова, а за шумску вегетацију су значајни: Животне форме биљних врста и биолошки спектар флоре СР Србије (у: Вегетација Србије 1, 1984), Вегетација шибљака (у: Вегетација Србије 2(1), 1997), Флора шибљака на планини Мирочу у источној Србији, са освртом на вегетацију (1958), Прилог познавању шумских и ливадских фитоценоза Озрена, Девице и Лесковика код Сокобање (1962), Прилог познавању вегетације шибљака јоргована (Syringa vulgaris L.) у источној Србији (Eryngio-Syringetum vulgaris Diklić ass. nova) (1965), Флора Јабланика и Медведника са освртом на вегетацију (1958).

МиЛОВАН ГАЈИЋ (Београд 1926-1994) се школовао у Београду. Дипломирао је на Пољопривредно-шумарском факултету у Земуну (Београд) и докторирао на Шумарском факултету у Београду (Фитоценозе и станишта планине Рудник и њихове деградационе фазе), на коме је провео и цео радни век напредујући до звања редовног професора. Добитник је Октобарске награде града Београда, Седмојулске награде СР Србије, Медаље за храброст и Ордена рада са златним венцем. Објавио је преко 200 научних радова а за шумску вегетацију су значајни: О вегетацији Кошутњака (1952), Прилог познавању храстово-грабових шума (Querceto-Carpinetum) Шумадије (1954), Фитоценозе и станишта планине Рудник и њихове деградационе фазе (1961), Флора Гоча-Гвоздац (1984), Флора и вегетација Голије и Јавора (1989), Вегетација националног парка Тара (1992), Оморика - Picea omorika (Pančić) Purkyne на подручју националног парка Тара (1994).

\footnotetext{
${ }^{1}$ Опширни приказ и анализа живота, рада, достигнућа, улоге и значаја Николе Диклића налазе се у: Vasić, O.: Nikola Diklić (1925-2008). - Bulletin of the Natural History Museum in Belgrade 2: 155-212, Beograd, 2009. и Vasić, O.: Nikola Diklić (1925-2008). - Flora Mediterranea 18: 615-640, Palermo, 2008.
} 
БУдислАв ТАТић (Прокупље: Туларе 1926-2010 Београд) се школовао у Лесковцу и Прокупљу. Дипломирао је на Природно-математичком факултету у Београду где је и докторирао (Флора и вегетација Студене планине код Краљева). Радио је као учитељ у селу Ргаје (тада Топлички срез), одакле је прешао на Природно-математички факултет у Београду где је напредовао до звања редовног професора. Добитник је Октобарске награде града Београда и Седмојулске награде СР Србије. Објавио је 100 научних радова, а за шумску вегетацију су значајни: Прилог познавању смрчевих шума Голије планине (1962), Флора и вегетација Студене планине код Краљева (1970), Шума цера и боровнице (Myrtillo-Quercetum cerris ass. nova) (1974), Нова реликтна заједница црног граба са јаворима (Aceri-Ostryetum carpinifoliae) на подручју југозападне Србије (1986), Шуме црног и белог бора, Ацидофилне шуме борова, Шуме Панчићеве оморике (у: Вегетација Србије 2(2), 2006).

МЛАДЕН КОРАЋ (Хрватска: Лика: Дебело Брдо 1926-2011 Београд) се школовао у Београду. Дипломирао је на Пољопривредно-шумарском факултету у Земуну (Београд) и на Природно-математичком факултету у Београду. Докторирао је у Загребу (Флора и вегетација шумског подручја планине Јухор). Био је професор у средњој школи у Београду, а затим је прешао на Шумарски факултет у Београду где је напредовао до звања редовног професора. Објавио је 50 радова, а за шумску вегетацију су значајни: О појави полигамије код Populus tremula (1958), Шикаре леске у долини Лепенца (1958), Панчићева оморика (Picea omorika Panč.) и јонизујуће зрачење (1965), Смрча са храстоликом кором (1978), Шума китњака - Quercetum montanum Čer. et Jov. на планини Јухор (1985), Деградирани стадијум субасоцијације Carpinetosum orientalis асоцијације Quercetum montanum на Јухору (1989).

Јосип ЕРДЕши (Бач 1927-2005 Сремска Митровица) се школовао у Сомбору, дипломирао на Пољопривредно-шумарском факултету у Земуну (Београд) и докторирао на Шумарском факултету у Београду (Фитоценозе шума југозападног Срема). Радио је у Шумској управи Моровић (Шумско газдинство Сремска Митровица), био је управник Шумске управе Вишњићево и самостални референт у Шумском газдинству Сремска Митровица. У оквиру Шумског газдинства основао је Педолошку лабораторију и организовао Семенску службу. Објавио је 50 научних радова, а за шумску вегетацију су значајни: Усуканост код јасена (1957), Низинска јасика Војводине и сива топола (1965), Фитоценозе шума југозападног Срема (1971), Нове форме и налазишта лужњака у СРС (1977), Нове форме и нова налазишта цера у СРС и СФРЈ (1977), Иконографија храста лужњака Југославије (1985). 
АЛЕКСАНДАР ТУцОВИЋ (Земун 1928-2004 Београд) се школовао у Београду. Дипломирао је на Шумарском факултету и Природноматематичком факултету у Београду. Докторирао је на Шумарском факултету (Систематска и биоеколошка истраживања црне тополе (Populus nigra L. у Србији) где је провео и цео радни век напредујући до звања редовног професора, а предавао је и на Пољопривредном факултету у Новом Саду. Био је члан Њујоршке академије наука. Добитник је Октобарске награде града Београда, Седмојулске награде СР Србије, Златне плакете Шумарског факултета и Шумске управе Делиблатски песак, као и две Захвалнице Министарства за пољопривреду САД. Написао је преко 300 научних радова а за шумску вегетацију су значајни: Прилог познавању дендрофлоре Београда и околине (1954), Утицај ниских температура на алохтону дендрофлору Београда и околине у току зиме 1955/56 године (1957), Нови хибриди топола произведени у 1958. години (1960), Масовна и индивидуална селекција букве у Србији (1967), Аутохтоне тополе Делиблатске пешчаре (1969), Индивидуална селекција стабала домаћег (Juglans regia L.) и црног ораха (Juglans nigra L.) (1973), Генетика храстова лужњака и китњака (Quercus robur L. и Quercus petraea Liebl.) (1975).

ВидАК ЈОвАНОвИЋ (Лесковац 1931-2000) се школовао у Лесковцу, дипломирао на Вишој педагошкој школи у Нишу и на Природноматематичком факултету у Скопљу, магистрирао у Загребу (Флора и вегетација северног дела Кукавице у југоисточној Србији) и докторирао у Новом Саду (Ливадска вегетација југоисточне Србије - планине Радан, Гољак, део Кукавице и њихове околине). Радио је у основној школи и као просветни саветник у Лесковцу. Био је професор на Вишој педагошкој школи у Београду и на Технолошком факултету у Лесковцу, а предавао је и на Учитељском факултету у Врању. Објавио je 50 научних радова, а значајни за шумску вегетацију су: Планина Кукавица у југоисточној Србији и вегетација њеног северног дела (1977), Шумска вегетација шире околине Медвеђе у јужној Србији (1984), Распрострањење фитоценозе храста сладуна (Quercetum farnetto Jov.) у Лесковачкој котлини (1982), Реликтна вегетација у пределу Козарник-Клисура-Св. Илија у јужној Србији (1982), Реликтна вегетација Мркоњског виса у јужној Србији (1983), Quercetum montanum s. lat. као климарегионални тип шуме јужне Србије (1984), Шума питомог кестена, китњака и грабића (Carpino orientalis-Querco-Castanetum sativae ass. nova) у околини Врања (1998/1999).

ЗАГОРКА УвАЛИЋ ТОМИЋ (Српски Милетић: Оџаци 1938-) се школовала у Сомбору и дипломирала на Шумарском факултету у Београду, где је и магистрирала (Фитоценозе Липовице) и докторирала (Фитоценозе црног граба (Ostria carpinifolia Scop.) у Србији). Цео 
радни век је провела на Шумарском факултету у Београду где је напредовала до звања редовног професора. Члан је Одбора за флору и вегетацију Српске академије наука и уметности. Објавила је 80 научних радова, а најважнији су: Фитоценозе Липовице (1972), Фитоценозе букве на Букуљи (1976), Еколошке јединице Бањске шуме у околини Бора, Фитоценозе црног граба (Ostrya carpinifolia Scop.) у Србији (1980), Шумски екосистеми у ширем подручју Обедске баре (1984), Заједница Orno-Quercetum-cerris virgilianae Jov. et. Vuk. 1977 на јужном ободу Паноније (1991), Заједница црнога бора и црнога граба - Ostryo-Pinetum nigrae Čol. 1965. на Тари (1994), Заједница Orno-Ostryetum Aich. 33 у рефугијумима југозападне Србије (2000), Заједница Quercetum farnetto-cerris scardicum Krasn. 1968 (2000), Прилог познавању асоцијације Quercetum montanum Čer. et. Jov. 1953. у североисточној Србији (2003), Шуме црног граба, Шуме црног и белог бора, Ацидофилне шуме борова, Преглед синтаксона шумске вегетације Србије (у Вегетација Србије 2(2), 2006), Избор врста за пошумљавање и мелиорације у централној Србији (2011).

АнкА Динић (Београд 1938-) се школовала у Београду, где је и дипломирала на Шумарском факултету. Магистрирала је и докторирала на Природно-математичком факултету у Београду (Граб (Carpinus betulus L.) у шумским заједницама Фрушке Горе; Екологија и варијабилитет граба (Carpinus betulus L.) и његово учешће у шумским заједницама северне Србије). Цео радни век је провела у Институту за биолошка истраживања „Синиша Станковић“ у Београду где је напредовала до звања научног саветника. Члан је Матице српске и Одбора за флору и вегетацију Српске академије наука и уметности. Добитник je Октобарске награде града Београда, Дипломе Српског биолошког друштва и Захвалнице Републичког завода за заштиту природе СР Србије. Објавила је око 250 научних радова, а најзначајнији су: Граб (Carpinus betulus L.) у шумским заједницама Фрушке горе (1970), Фитоценоза граба (Chrysosplenio-Carpinetum betuli ass. nova) на алувијално-делувијалном наносу у северној Србији (1972), Еколошка студиja граба (Carpinus betulus L.) на примеру типичног вегетацијског трансекта на Авали (1975), Варијабилитет и еколошка диференцијација граба (Carpinus betulus L.) у северној Србији (1975), Фитоценоза китњака и граба као климарегионални тип шуме на малим масивима у северној Србији, на ободу Панонске низије (1978), Биљне заједнице и станишта Старе планине (1978), Утицај летње суше на међусобне односе биљних врста и састав и динамику климатогене заједнице сладуна и цера (Quercetum farnetto cerris serbicum Rudski) (1984), Експериментална испитивања клијавости семена Панчићеве оморике на различитим стаништима у резервату Црвени поток на планини Тари (1989), Експериментална фитоценологија шумских екосистема 
Србије (1994), Свеза китњаково-грабових и чистих грабових шума (Carpinion betuli moesiacum Rudski B. Jov. 1986) (у Вегетација Србије 2(1), 1997), Еколошка диференцијација врста шумског дрвећа у Србији (2004), Шуме смрче, Шуме Панчићеве оморике (у Вегетација Србије 2(2), 2006). 